\title{
The effect of the support on the surface composition of PtCu alloy nanocatalysts: In situ XPS and HS-LEIS studies
}

\author{
Junjie Huang, Yanying Song, Dongdong Ma, Yanping Zheng, Mingshu Chen *, Huilin Wan \\ State Key Laboratory of Physical Chemistry of Solid Surfaces, National Engineering Laboratory for Green Chemical Productions of Alcohols-Ethers-Esters, \\ Department of Chemistry, College of Chemistry and Chemical Engineering, Xiamen University, Xiamen 361005, Fujian, China
}

\section{A R T I C L E I N F O}

\section{Article history:}

Received 11 April 2017

Accepted 12 May 2017

Published 5 July 2017

\section{Keywords:}

PtCu alloy

Bimetal catalyst

Surface composition

Phase diagram

In situ XPS-LEIS

\begin{abstract}
A B S T R A C T
Supported PtCu alloys have been broadly applied in heterogeneous catalysis and electrocatalysis owing to their excellent catalytic performance and high CO tolerance. It is important to analyze the outermost surface composition of the supported alloy nanoparticles to understand the nature of the catalytically active sites. In this paper, homogeneous face-centered cubic PtCu nanoparticles with a narrow particle size distribution were successfully fabricated and dispersed on a high-surface-area $\mathrm{TiO}_{2}$ powder support. The samples were oxidized and reduced in situ and then introduced into the ultrahigh vacuum chamber to measure the topmost surface composition by high-sensitivity low-energy ion scattering spectroscopy, and to determine the oxidation states of the elements by $\mathrm{X}$-ray photoelectron spectroscopy. The surface composition and morphology, elemental distribution, and oxidation states of the components were found to be significantly affected by the support and treatment conditions. The $\mathrm{PtCu}$ is de-alloyed upon oxidation with $\mathrm{CuO}$ wetting on the $\mathrm{TiO}_{2}$ surface and re-alloyed upon reduction. Phase diagrams of the surface composition and the bulk composition were plotted and compared for the supported and unsupported materials.
\end{abstract}

(C) 2017, Dalian Institute of Chemical Physics, Chinese Academy of Sciences. Published by Elsevier B.V. All rights reserved.

\section{Introduction}

Noble metal alloy catalysts have been used for a number of applications [1-10]. In recent years, Pt-based alloys have been widely used in various fields to reduce the amount of Pt used. Among these alloys, the PtCu alloy is one of the most common alloy catalysts used in heterogeneous catalysis and electrocatalysis [2-10]. Adding $\mathrm{Cu}$ can improve the catalytic efficiency of $\mathrm{Pt}$, leading to a reduction in the cost and enhancement in the catalytic performance. Most studies of PtCu alloy nanoparticles focus on tuning the size and morphology for improving their catalytic activities [11-14]. Different types of PtCu alloy nanoparticles including cubes, octahedrons, nanowires, rhombic dodecahedra, nanodendrites, and cubic cages have been successfully synthesized [15-25].

The morphology and surface composition are the most important factors that influence the catalytic performance [26,27]. However, most industrial catalysts are supported on oxides to improve their efficiency and catalytic performance. Upon supporting nanoparticles onto oxide supports, their morphology, composition, and catalytic performance may change owing to their interaction with the support [28-35]. The so-called support effect often occurs at the metal/oxide interface by encapsulation [31] or high dispersion [32-35]. Among which, strong metal-support interaction (SMSI) is the most famous one [28-30]. Therefore, it is crucial to determine the dispersion, the

\footnotetext{
* Corresponding author. Tel/Fax: +86-592-2183723; E-mail: chenms@xmu.edu.cn

This work was supported by the National Basic Research Program of China (973 Program, 2013CB933102), the National Natural Science Foundation of China (21273178, 21573180, 91545204), and Xiamen-Zhuoyue Biomass Energy Co. Ltd.

DOI: 10.1016/S1872-2067(17)62857-2 | http://www.sciencedirect.com/science/journal/18722067 | Chin. J. Catal., Vol. 38, No. 7, July 2017
} 
surface composition as a function of the bulk composition, of an alloy catalyst.

In this paper, homogeneous $\mathrm{PtCu}$ alloy nanoparticles were successfully synthesized by a solvothermal method [36]. The obtained nanoparticles were loaded on common oxide supports. In situ X-ray photoelectron spectroscopy (XPS) [37-41] and high-sensitivity low-energy ion scattering spectroscopy (HS-LEIS) [42-44] were used to characterize the chemical states and compositions after different treatments. Phase diagrams of the surface composition as a function of the bulk composition were obtained and compared with those of unsupported $\mathrm{PtCu}$ alloy nanoparticles.

\section{Experimental}

\subsection{Catalyst synthesis}

PtCu alloy: $4.0 \mathrm{mg}$ of $\mathrm{Pt}(\mathrm{acac})_{2}$ and $8.0 \mathrm{mg}$ of $\mathrm{Cu}(\mathrm{acac})_{2}$ were dissolved in $3.0 \mathrm{~mL}$ of DMF under ultrasonication. Subsequently, $10.0 \mathrm{~mL}$ of CTAC ( $0.01 \mathrm{~mol} / \mathrm{L}$ in DMF) solution was injected under vigorous stirring. The mixed solution was further stirred for $30 \mathrm{~min}$ and then transferred into a $20-\mathrm{mL}$ Teflon-lined stainless-steel autoclave. The sealed vessel was heated from room temperature to $160{ }^{\circ} \mathrm{C}$, maintained at this temperature for $10 \mathrm{~h}$, and then naturally cooled to room temperature. The products were collected by centrifugation $(9000 \mathrm{r} / \mathrm{min}$ for 5 min), and then washed several times with ethanol to remove any impurities.

$\mathrm{PtCu} / \mathrm{TiO}_{2}$ alloy nanocatalysts: The PtCu alloy nanoparticles were uniformly dispersed in ethanol under ultrasonication and loaded on the $\mathrm{TiO}_{2}$ support (P25) using an impregnation method and then dried at $80{ }^{\circ} \mathrm{C}$ under vacuum overnight.

\subsection{Catalyst characterization}

Transmission electron microscopy (TEM) and high-resolution TEM (HRTEM) images were conducted on a transmission electron microscope (JEM-2100) operated at 200 $\mathrm{kV}$. High angle annular dark field scanning transmission electron microscopy (HAADF-STEM) and energy-dispersive X-ray analysis spectroscopy (EDS) were performed using a FEI TECNAI F30 high-resolution transmission electron microscope operating at $300 \mathrm{kV}$. All samples subjected to TEM measurements were prepared by impregnating the diluted suspension in ethanol under ultrasonication with molybdenum grids (Beijing Xinxing Braim Technology Co. Ltd.). The Pt and Cu contents were analyzed quantitatively by an inductively coupled plasma-optical emission spectrometer (ICP-OES, IRIS Intrepid II XSP). X-ray powder diffraction (XRD) measurements were recorded on a Rigaku Ultima IV X-ray diffractometer employing $\mathrm{Cu}$ $K_{\alpha}$ radiation at $35 \mathrm{kV}$ and $15 \mathrm{~mA}$. The surface compositions of the alloy were determined by XPS (Qtac-100 LEIS-XPS) using monochromatic $\mathrm{Al} K_{\alpha}(1486.6 \mathrm{eV})$ radiation. The binding energies were calibrated with respect to the signal for Ti of the titania support (P25, Ti $2 p_{3 / 2}$ binding energy of $458.8 \mathrm{eV}$ ). The outermost surface compositions were detected by LEIS with $\mathrm{Ne}^{+}$. The related peak area sensitivities were calibrated by pure metal platinum and copper, $\mathrm{TiO}_{2}(110)$.

\section{Results and discussion}

The representative HAADF-STEM images (Fig. 1(a, b)) reveal that PtCu nanoparticles were successfully prepared with a uniform size of ca. $13 \mathrm{~nm}$. Both Pt and Cu were homogeneously distributed in each alloy particle, as indicated by the EDS ele-
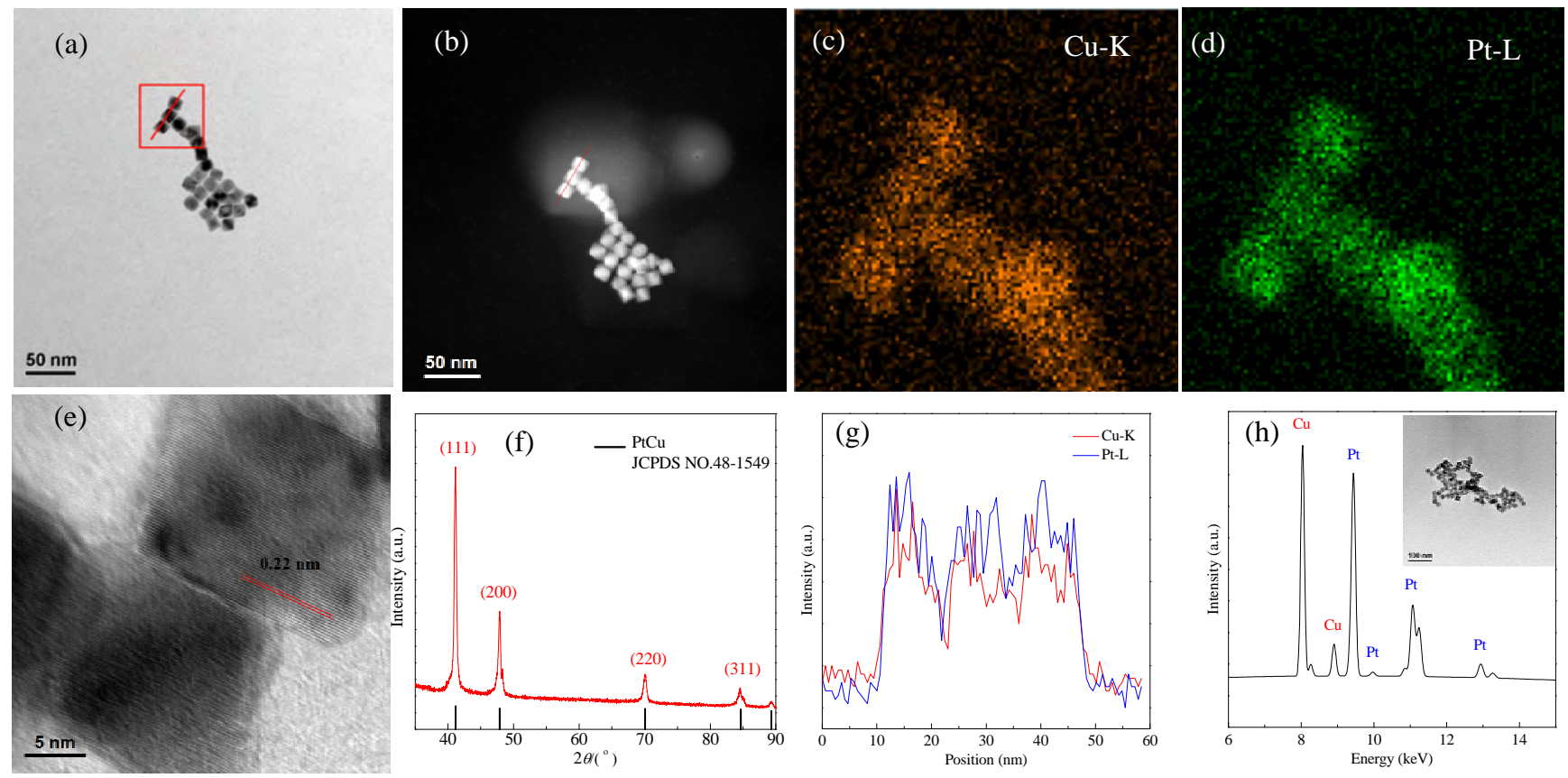

Fig. 1. TEM (a), HAADF-STEM (b), EDS elemental mapping (c, d) images of PtCu alloy nanoparticles, high-magnification TEM images (e), XRD patterns (f), the cross-sectional compositional line profiles (g), and EDS (h) of the PtCu alloy nanoparticles. 
Table 1

Composition of the as-prepared PtCu alloy nanoparticles.

\begin{tabular}{lcccc}
\hline Element & $\begin{array}{c}\text { Theoretical feed } \\
\text { ratio }\end{array}$ & XRD & $\begin{array}{c}\text { ICP-OES } \\
\text { (mol \%) }\end{array}$ & $\begin{array}{c}\text { EDS } \\
\text { (atomic \%) }\end{array}$ \\
\hline $\mathrm{Pt}$ & 1 & 1 & 0.55 & 52.5 \\
$\mathrm{Cu}$ & 3 & 1 & 0.45 & 47.5 \\
\hline
\end{tabular}

mental mapping images in Fig. 1(c, d) and the cross-sectional compositional line profiles in Fig. 1(g). A lattice distance of ca. $0.22 \mathrm{~nm}$ was observed in the high-magnification TEM image (Fig. 1(e)), which corresponds to the crystal lattice of the (111) planes of the face-centered-cubic PtCu alloy [36]. XRD pattern of the as-prepared nanoparticles only shows a group of peaks corresponding to PtCu alloy (JCPDS NO. 48-1549). No additional diffraction peaks from either $\mathrm{Pt}$ or $\mathrm{Cu}$ were detected, as shown in Fig. 1(f). The sharp peaks and perfect match between the diffraction peaks of the PtCu nanoparticles and standard $\mathrm{PtCu}$ alloy indicated the high crystallinity of the alloy $\mathrm{PtCu}$ phase. The EDS (Fig. 1(h)) and ICP-OES data both showed that each $\mathrm{PtCu}$ nanoparticle was composed of $\mathrm{Pt}$ and $\mathrm{Cu}$ with a close atomic ratio of 1:1 (Table 1). All the above information confirmed the formation of a homogeneous single-phase $\mathrm{PtCu}$ alloy nanoparticle.

The $\mathrm{PtCu} / \mathrm{TiO}_{2}$ sample was calcined at $250{ }^{\circ} \mathrm{C}$ in air for $2 \mathrm{~h}$ to remove the CTAC surfactant. XRD results (Fig. 2) show that the $\mathrm{PtCu}$ alloy phase is stable and still exists after calcining at $300{ }^{\circ} \mathrm{C}$, but shifts to a lower angle after it was calcined at higher temperature and reduced under $\mathrm{H}_{2}$. This suggested the formation of Pt-rich $\mathrm{PtCu}_{x}$ alloys.

XPS analysis was performed to investigate the chemical state and composition for the $\mathrm{PtCu} / \mathrm{TiO}_{2}$ samples. The atomic percentages of the elements were calculated from the normalized peak areas. The binding energy of Ti $2 p_{3 / 2}$ at $458.8 \mathrm{eV}$ was used as a reference. The $\mathrm{C} 1 \mathrm{~s}$ peak at $284.6 \mathrm{eV}$ is commonly used as a reference. However, for the $\mathrm{PtCu} / \mathrm{TiO}_{2}$ with successive redox process, the $\mathrm{C} 1 \mathrm{~s}$ peak intensity was very weak and broad. Because $\mathrm{TiO}_{2}$ is the support and is considerably stable during the redox process, $\mathrm{Ti} 2 p_{3 / 2}$ at $458.8 \mathrm{eV}$ for $\mathrm{TiO}_{2}$ was a better reference value. The XPS spectra of $\mathrm{Pt} 4 f$ for the $\mathrm{Pt} / \mathrm{TiO}_{2}$ and $\mathrm{PtCu} / \mathrm{TiO}_{2}$ samples are presented in Fig. 3(a). The Pt $4 f_{7 / 2}$ for the $\mathrm{Pt} / \mathrm{TiO}_{2}$ is ca. $71.0 \mathrm{eV}$, corresponding to metallic Pt. A negative shift of $0.6 \mathrm{eV}$ was observed for the $\mathrm{PtCu} / \mathrm{TiO}_{2}$ [45], consistent with the XRD result for the formation of PtCu alloy. The XPS spectra of $\mathrm{Cu} 2 p_{3 / 2}$ for the $\mathrm{Cu} / \mathrm{TiO}_{2}$ are shown in Fig. 3(b). The calcined sample shows a broad peak at $934.4 \mathrm{eV}$ with a shoulder at $932.5 \mathrm{eV}$, characteristic of $\mathrm{Cu}^{2+}$ and $\mathrm{Cu}^{0} / \mathrm{Cu}^{+}$, respectively. The reduced sample shows a peak at $931.8 \mathrm{eV}$ corresponding to $\mathrm{Cu}^{0}$ [46]. For the $\mathrm{PtCu} / \mathrm{TiO}_{2}$ sample, the $\mathrm{Cu} 2 p_{3 / 2}$ features are obviously different from those for the $\mathrm{Cu} / \mathrm{TiO}_{2}$. The peak for the alloy PtCu at $931.8 \mathrm{eV}$ disappears quickly and the $\mathrm{Cu}^{2+}$ peak gradually increases during the oxidation process in Fig. 3(c). After the sample is reduced again, the $\mathrm{Cu} 2 p_{3 / 2}$ peak moves to $932.1 \mathrm{eV}$, which is slightly higher than that of 931.8 $\mathrm{eV}$ for the as-prepared alloy clusters in Fig. 3(d). This reveals that after the oxidation-reduction cycle, the alloy clusters become Pt rich, which may result from the high dispersion of $\mathrm{Cu}$ on the $\mathrm{TiO}_{2}$ surface. The XRD (Fig. 2(b)) and TEM (not shown) analyses also confirm that the $\mathrm{PtCu}$ alloy phase cannot be fully recovered, and a Pt-rich $\mathrm{PtCu}_{x}$ alloy phase forms after the oxidation-reduction cycle.

The $\mathrm{Cu} 3 p_{3 / 2}$ peak is at approximately $75 \mathrm{eV}$, which overlaps with the Pt $4 f$ peak. It is important to deconvolute the $\mathrm{Cu} 3 p_{3 / 2}$ peak from the Pt $4 f$ peak to distinguish the surface Pt species. The Pt $4 f$ can be fitted into three peaks (Fig. 4), 71.0-71.1 eV for the metallic $\mathrm{Pt}, 71.8-71.9 \mathrm{eV}$ for $\mathrm{Pt}^{\delta_{+}}$that bonds with oxygen [47], and 70.4-70.5 eV for Pt alloyed with $\mathrm{Cu}$. After oxidation at $450{ }^{\circ} \mathrm{C}$, the peak for the alloying Pt disappears, whereas the peaks for metallic $\mathrm{Pt}$ and $\mathrm{Pt}^{\delta_{+}}$gradually increase. Finally, the peak for the metallic Pt becomes dominant. Oxidation of the pre-reduced sample (Fig. 4(b)), metallic and $\mathrm{Pt}^{\delta_{+}}$always coexist. The difference in the Pt species obtained by direct oxidation and oxidation of pre-reduction could result from the different dispersion of Pt. After reduction, Pt species interacted with $\mathrm{Cu}^{0}$ to form an alloy phase again, with a small amount of $\mathrm{Pt}^{\delta_{+}}$, probably owing to the interaction between $\mathrm{Pt}$ atoms and $\mathrm{TiO}_{2}$ or $\mathrm{CuO}_{x}$. The relative intensities of the different $\mathrm{Pt}$ species obtained from the peak area in the curve fitting as a function of the treating temperatures are summarized in Fig. 5.
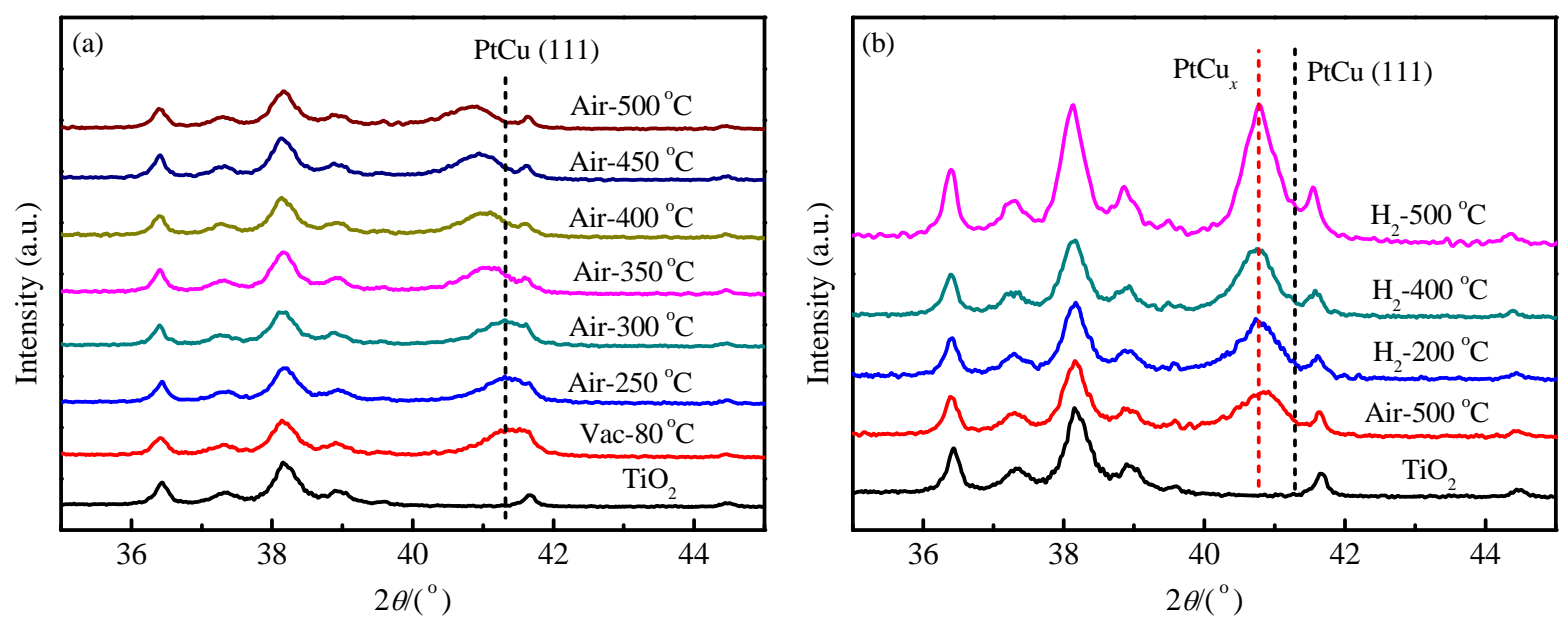

Fig. 2. XRD patterns of $\mathrm{PtCu} / \mathrm{TiO}_{2}$ catalysts under air (a) and $\mathrm{H}_{2}$ (b) at different temperatures. 

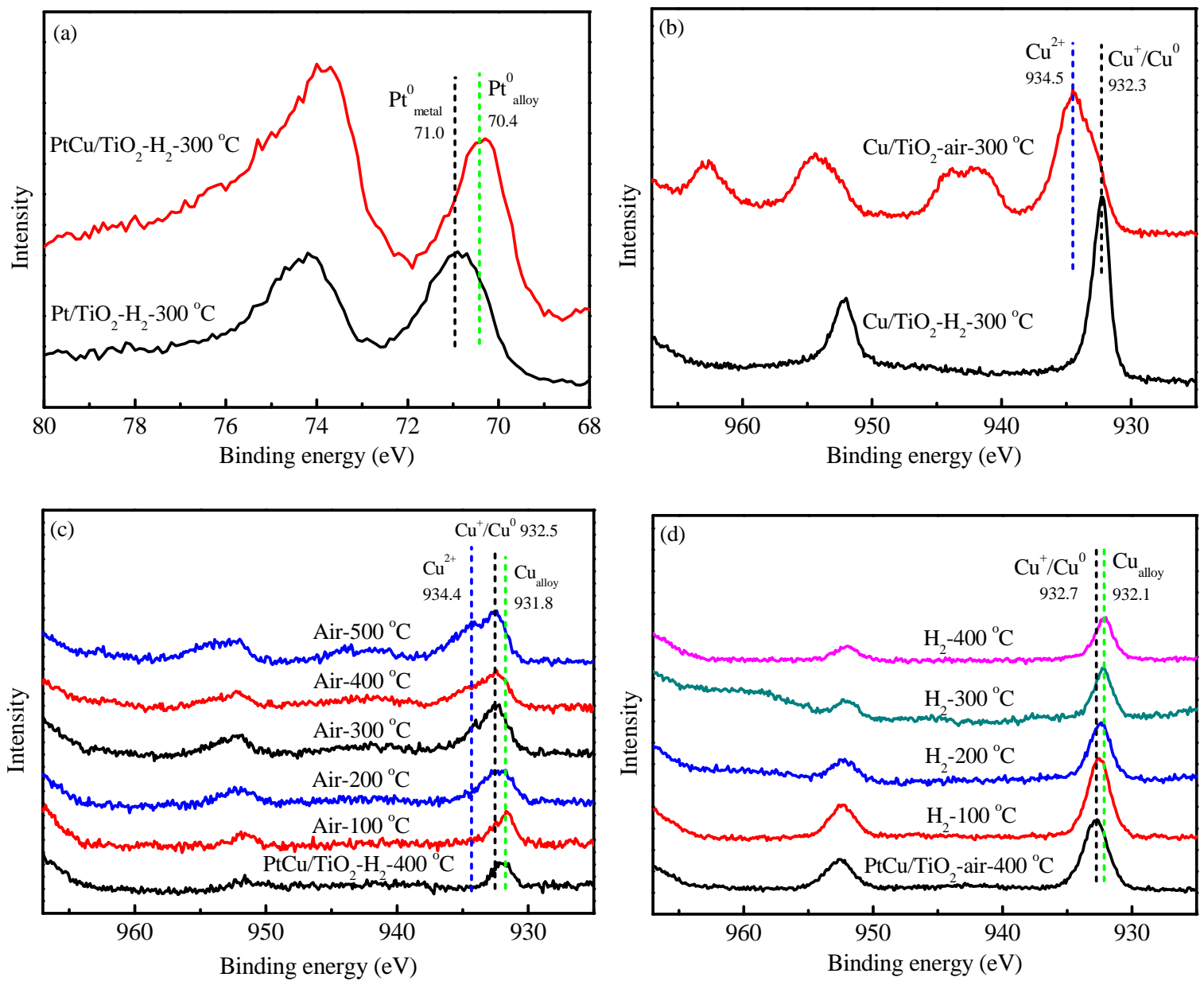

Fig. 3. $\mathrm{Pt} 4 f(\mathrm{a})$ and $\mathrm{Cu} 2 p$ (b) XPS spectra of $\mathrm{Cu} / \mathrm{TiO}_{2}$, and $\mathrm{Cu} 2 p$ XPS spectra of $\mathrm{PtCu} / \mathrm{TiO}_{2}$ after the successive treatment with air (c) and $\mathrm{H}_{2}$ (d).
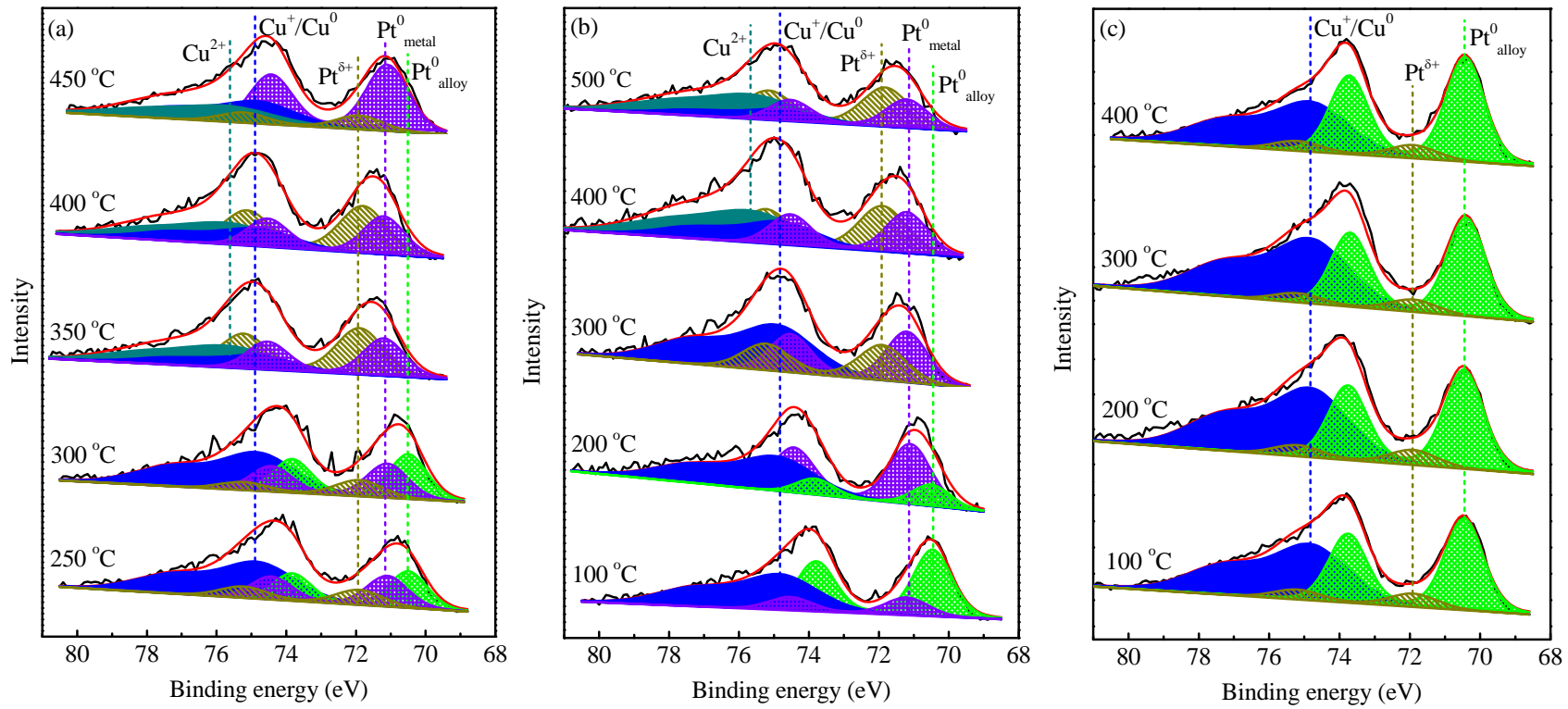

Fig. 4. Pt 4 XPS spectra with peak fitting under direct oxidation (a), oxidation (b) of the pre-reduced $\mathrm{PtCu} / \mathrm{TiO}_{2}$, and reduction (c) of the pre-oxidized $\mathrm{PtCu} / \mathrm{TiO}_{2}$.

The relative area ratios from both XPS and LEIS for the $\mathrm{PtCu} / \mathrm{TiO}_{2}$ sample during oxidation are shown in Fig. 6. After depositing PtCu nanoparticles onto the $\mathrm{TiO}_{2}$ support and oxidation, both the $\mathrm{Cu} / \mathrm{Ti}$ and $\mathrm{Cu} /(\mathrm{Cu}+\mathrm{Pt})$ ratios increase signifi- 

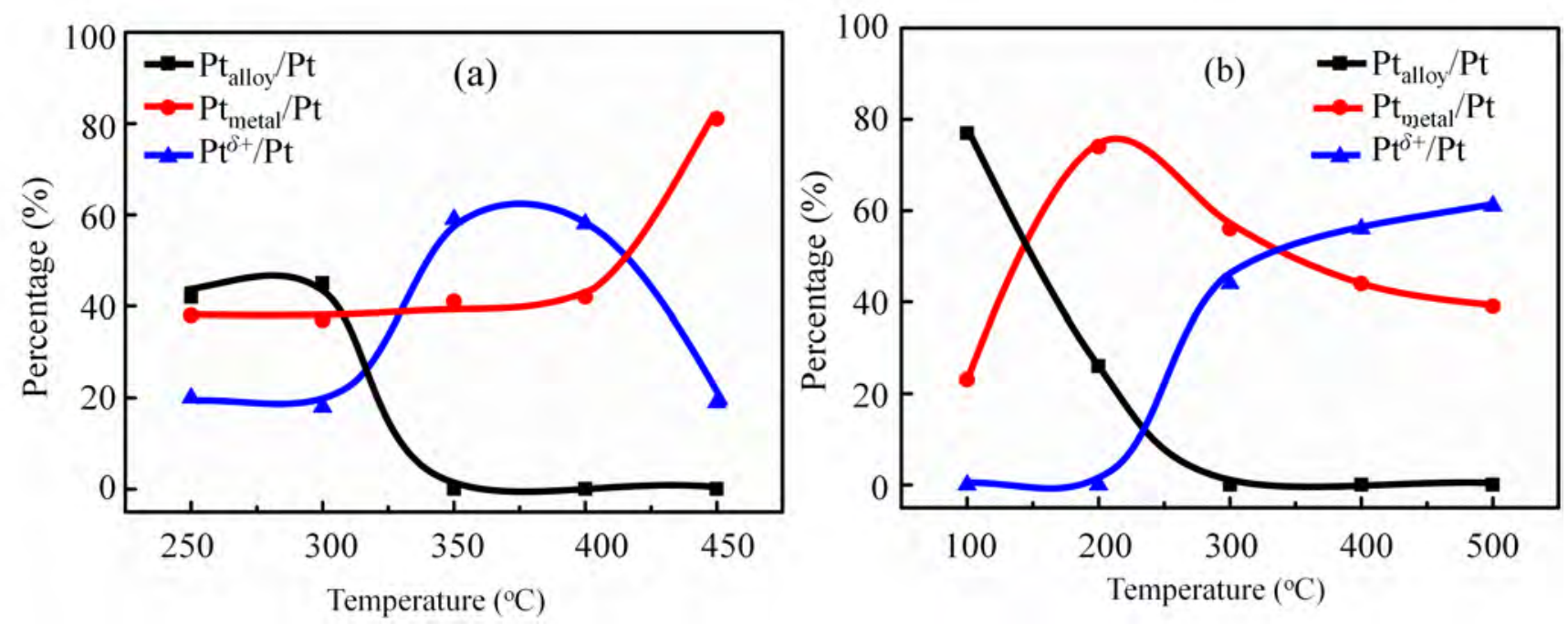

Fig. 5. The amount of the different Pt species from in situ XPS under direct oxidation (a) and oxidation of the pre-reduced (b) $\mathrm{PtCu} / \mathrm{TiO}_{2}$.
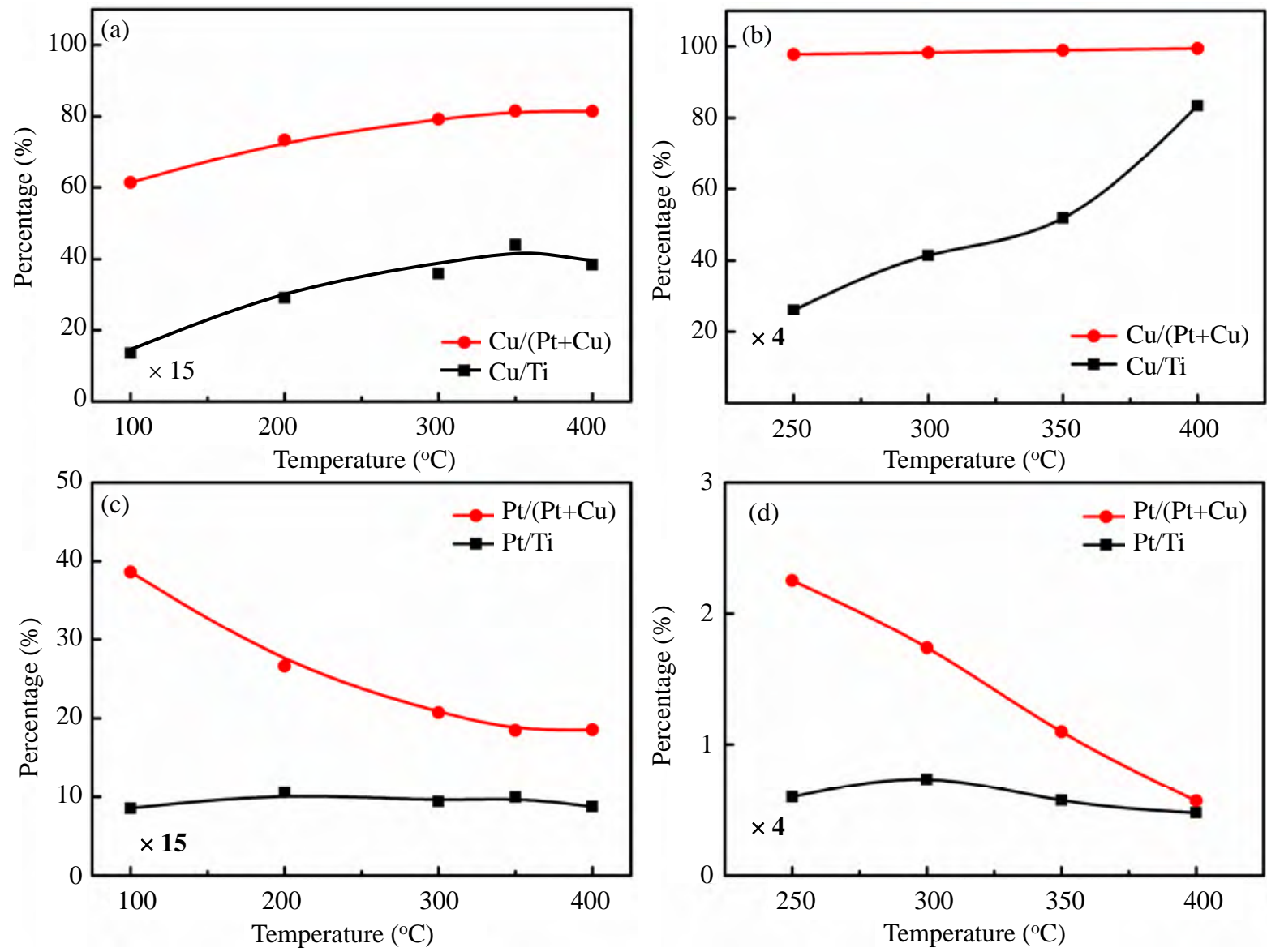

Fig. 6. Variation curves of the relative content of elemental $\mathrm{Pt} / \mathrm{Cu}$ on the surface of $\mathrm{PtCu} / \mathrm{TiO}_{2}$ acquired by XPS (a, c) and LEIS (b, d) during the oxidation process.

cantly, but there is no significant change in the Pt/Ti ratios. The decrease of the $\mathrm{Pt} /(\mathrm{Cu}+\mathrm{Pt})$ ratios is clearly evident and is caused by the increase in $\mathrm{Cu}$ content. These results indicate that de-alloying occurs with $\mathrm{Cu}$ spreading out predominately on the surface, and Pt clustering during the oxidation process [48]. In contrast, upon reduction of the pre-oxidized sample, the XPS $\mathrm{Cu} / \mathrm{Ti}$ ratio decreased (Fig. 7(a)), whereas the XPS
Pt/Ti ratio remained almost constant (Fig. 7(c)). Such tendencies are more apparent in the LEIS (Fig. 7(b, d)). Combined with the core-level binding energies from XPS, it can be concluded that part of $\mathrm{Cu}$ re-alloys with $\mathrm{Pt}$ during the reduction process. The surface $\mathrm{Cu}$ amount is much higher than that of the alloy surface as well as the bulk composition.

The above results show that the support has a significant 

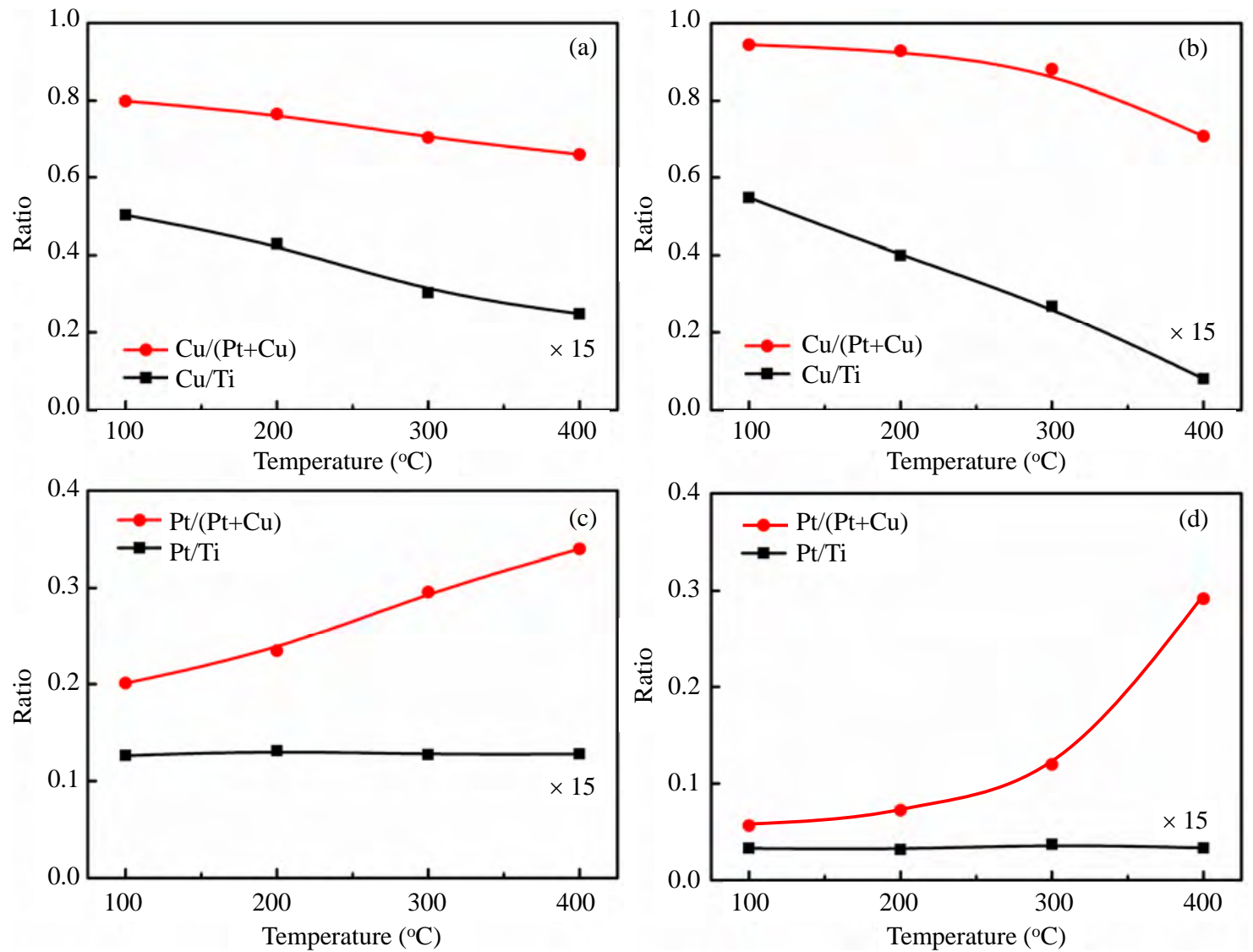

Fig. 7. Variation curves of the relative content of elemental $\mathrm{Pt} / \mathrm{Cu}$ on the surface of $\mathrm{PtCu} / \mathrm{TiO}_{2}$ acquired by XPS (a, c) and LEIS (b, d) during the reduction process.

effect on the dispersion and morphology of the alloy nanoparticles. It is important to understand the surface composition of the supported alloy nanoparticles. A phase diagram of the surface composition versus their bulk composition is the most intuitive to graphically display such alloy effects (Fig. 8). The Pt/total metal ratios obtained by both XPS and LEIS are significantly lower than in the bulk, which indicates that $\mathrm{Cu}$ domi- nates and disperses on the surface. For the unsupported $\mathrm{PtCu}_{x}$ samples, the surface Pt is also much lower than the bulk Pt under both the oxidation and reduction processes. The Pt ratio of the supported sample is higher when reduced at $400{ }^{\circ} \mathrm{C}$ but lower when oxidized at $400{ }^{\circ} \mathrm{C}$ than those for the unsupported samples. This demonstrates that the support plays a key role in determining the surface composition of an alloy sample.
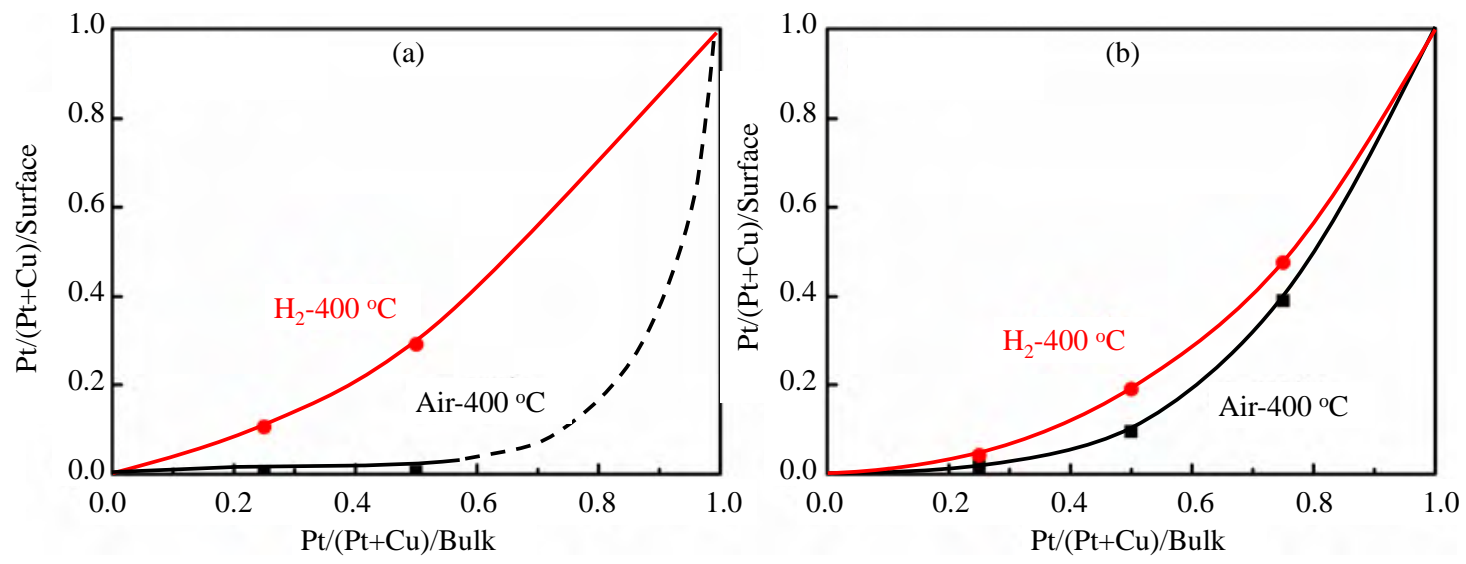

Fig. 8. Phase diagrams of the surface composition versus the bulk composition for (a) supported PtCu $\mathrm{u}_{x}$ alloy catalysts, and (b) unsupported PtCu bimetallic catalysts. 


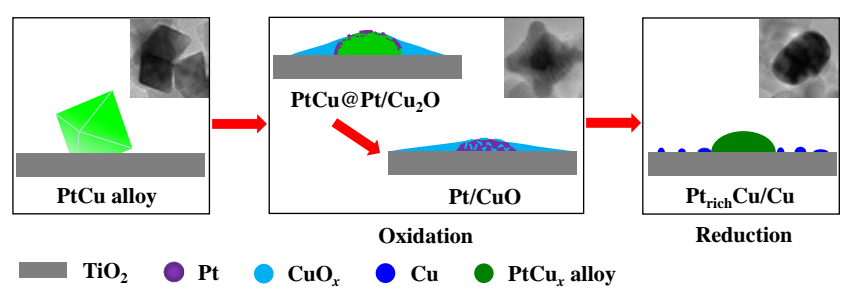

Scheme 1. Schematic drawing of the redox process for the surface properties and change rule $\mathrm{PtCu} / \mathrm{TiO}_{2}$ alloy nanoparticles.

The changes of the chemical state, morphology and composition of the $\mathrm{PtCu} / \mathrm{TiO}_{2}$ alloy nanoparticles are illustrated in Scheme 1 . According to the core-level binding energy shift of $\mathrm{Cu}$ $2 p$ and $\mathrm{Pt} 4 f$, the change of $\mathrm{Cu}^{0}$ to $\mathrm{Cu}^{2+}$ and $\mathrm{Cu}^{+}$to $\mathrm{Cu}^{0}$ and small amount of $\mathrm{Cu}^{+}$during the oxidation and reduction processes, respectively, are confirmed. From the elemental ratios determined by XPS and LEIS, oxidation results in a significant increase of the surface $\mathrm{Cu}$ amount but not $\mathrm{Pt}$, which indicates that de-alloying occurs with $\mathrm{Cu}$ forming $\mathrm{CuO}$ wetting on the support surface. In contrast, reduction leads to a decrease in the amount of surface $\mathrm{Cu}$, which indicates that de-wetting and re-alloying occurs.

\section{Conclusions}

In summary, homogeneous face-centered cubic PtCu alloy nanoparticles were successfully synthesized by the solvothermal method and dispersed onto a $\mathrm{TiO}_{2}$ support. The surface composition and chemical states were investigated by in situ XPS and LEIS. Upon oxidation, de-alloying takes place with $\mathrm{Cu}$ being oxidized and well dispersed on the oxide support, whereas Pt being metallic and clustering. Reduction of the pre-oxidized $\mathrm{PtCu} / \mathrm{TiO}_{2}$ results in partial re-alloying of the surface $\mathrm{Cu}$ with Pt. The surface composition is significantly different from that of the bulk one, with a high $\mathrm{Cu}$ content on the surface. The support plays an important role in the dispersion of $\mathrm{Cu}$.

\section{References}

[1] M. S. Chen, D. Kumar, C. W. Yi, D. W. Goodman, Science, 2005, 310,
291-293.

[2] M. S. Chen, D. W. Goodman, Chin. J. Catal., 2008, 29, 1178-1186.

[3] T. Komatsu, A. Tamura, J. Catal., 2008, 258, 306-314.

[4] D. Liang, J. Gao, J. H. Wang, P. Chen, Y. F. Wei, Z. Y. Hou, Catal. Commun., 2011, 12, 1059-1062.

[5] S. H. Zhou, B. Varughese, B. Eichhorn, G. Jackson, K. Mcllwrath, Angew. Chem. Int. Ed., 2005, 44, 4539-4543.

[6] L. Y. Li, Z. Y. Xu, F. L. Liu, Y. Shao, J. H. Wang, H. Q. Wan, S. R. Zheng, J. Photochem. Photobio. A, 2010, 212, 113-121.

[7] J. Knudsen, A. U. Nilekar, R. T. Vang, J. Schnadt, E. L. Kunkes, J. A. Dumesic, M. Mavrikakis, F. Besenbacher, J. Am. Chem. Soc., 2007, $129,6485-6490$.

[8] F. Papa, A. Miyazaki, M. Scurtu, A. C. Ianculescu, I. Balint, J. Nanopart. Res., 2014, 16, 2249/1-2249/12.

[9] W. J. Kang, R. Li, D. H. Wei, S. L. Xu, S. Y. Wei, H. B. Li, RSC Adv., 2015, 5, 94210-94215.

[10] H. Xu, Q. Fu, X. H. Bao, Chin. J. Catal., 2013, 34, 2029-2035.

[11] H. D. Zhao, C. Z. Yu, H. J. You, S. C. Yang, Y. Guo, B. J. Ding, X. P. Song, J. Mater. Chem., 2012, 22, 4780-4789.

[12] Y. X. Wang, H. J. Zhou, P. C. Sun, T. H. Chen, J. Power Sources, 2014, 245, 663-670.

[13] Y. J. Li, F. X. Quan, E. B. Zhu, L. Chen, Y. Huang, C. F. Chen, Nano Res., 2015, 8, 3342-3352.

[14] G. L. Zhang, Z. Z. Yang, W. Zhang, H. W. Hu, C. Z. Wang, C. D. Huang, Y. X. Wang, Nanoscale, 2016, 8, 3075-3084.

[15] D. Xu, S. Bliznakov, Z. D. Liu, J. Y. Fang, N. Dimitrov, Angew. Chem. Int. Ed., 2010, 49, 1282-1285.

[16] X. Y. Zhao, B. B. Luo, R. Long, C. M. Wang, Y. J. Xiong, J. Mater. Chem. A, 2015, 3, 4134-4138.

[17] Y. Q. Jiang, Y. Y. Jia, J. W. Zhang, L. Zhang, H. Huang, Z. X. Xie, L. S. Zheng, Chem. Eur. J., 2013, 19, 3119-3124.

[18] Y. Y. Jia, Y. Q. Jiang, J. W. Zhang, L. Zhang, Q. L. Chen, Z. X. Xie, L. S. Zheng, J. Am. Chem. Soc., 2014, 136, 3748-3751.

[19] J. P. Lai, L. Zhang, W. J. Qi, J. M. Zhao, M. Xu, W. Y. Gao, G. B. Xu, ChemCatChem, 2014, 6, 2253-2257.

[20] M. L. Xiao, S. T. Li, X. Zhao, J. B. Zhu, M. Yin, C. P. Liu, W. Xing, ChemCatChem, 2014, 6, 2825-2831.

[21] W. Hong, J. Wang, E. Wang, Nano Res., 2015, 8, 2308-2316.

[22] B. Y. Xia, H. B. Wu, X. Wang, X. W. Lou, J. Am. Chem. Soc., 2012, 134, 13934-13937.

[23] E. Taylor, S. T. Chen, J. Tao, L. J. Wu, Y. M. Zhu, J. Y. Chen, ChemSusChem, 2013, 6, 1863-1867.

[24] S. F. Fu, C. Z. Zhu, Q. R. Shi, H. B. Xia, D. Du, Y. H. Lin, Nanoscale, 2016, 8, 5076-5081.

[25] X. H. Sun, K. Z. Jiang, N. Zhang, S. J. Guo, X. Q. Huang, ACS Nano,

\section{Graphical Abstract}

Chin. J. Catal., 2017, 38: 1229-1236 doi: 10.1016/S1872-2067(17)62857-2

\section{The effect of the support on the surface composition of $\mathrm{PtCu}$} alloy nanocatalysts: In situ XPS and HS-LEIS studies

Junjie Huang, Yanying Song, Dongdong Ma, Yanping Zheng, Mingshu Chen *, Huilin Wan

Xiamen University

Upon oxidation, de-alloying of $\mathrm{PtCu}$ takes place and $\mathrm{Cu}$ is oxidized and well dispersed on $\mathrm{a} \mathrm{TiO}_{2}$ support, whereas $\mathrm{Pt}$ is being metallic and clustering. Reduction results in partial re-alloying of $\mathrm{Cu}$ with Pt.

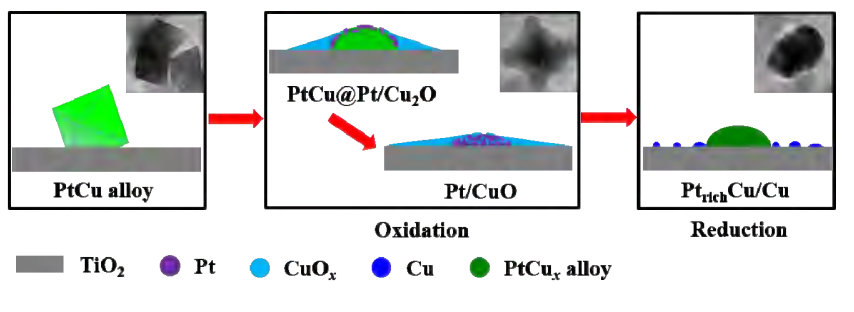


2015, 7, 7634-7640.

[26] J. N. Wang, H. X. Dai, H. He, Chin. J. Catal., 2011, 32, 1329-1335.

[27] C. M. Wang, S. Bai, Y. J. Xiong, Chin. J. Catal. 2015, 36, 1476-1493.

[28] S. J. Tauster, Acc. Chem. Res., 1987, 20, 389-394.

[29] Q. Fu, T. Wagner, Surf. Sci. Rep., 2007, 62, 431-498.

[30] D. S. Mao, G. Z. Lu, Q. L. Chen, Chin. J. Catal., 2004, 25, 501-510.

[31] S. Schauermann, N. Nilius, S. Shaikhutdinov, H. J. Freund, Acc. Chem. Res., 2013, 46, 1673-1681.

[32] Q. Fu, F. Yang, X. H. Bao, Acc. Chem. Res., 2013, 46, 1692-1701.

[33] X. N. Chen, J. Y. Chen, Y. Zhao, M. S. Chen, H. L. Wan, Chin. J. Catal., 2012, 33, 1901-1905.

[34] L. Dong, X. J. Yao, Y. Chen, Chin. J. Catal., 2013, 34, 851-864.

[35] X. J. Yao, F. Gao, L. Dong, Chin. J. Catal., 2013, 34, 1975-1985.

[36] Y. Y. Jia, J. Y. Su, Z. B. Chen, K. Tan, Q. L. Chen, Z. M. Cao, Y. Q. Jiang, Z. X. Xie, L. S. Zheng, RSC Adv., 2015, 5, 18153-18158.

[37] C. D. Wagner, W. M. Riggs, L. E. Davis, J. F. Mouler, G. E. Muilenberg, Handbook of X-ray Photoelectron Spectroscopy, Perkin-elmer Corporation, Physical Electronics Division, Eden Prairie, Minnesota, USA, 1979, 190.

[38] C. C. Chusuei, D. W. Goodman, X-ray Photoelectron Spectroscopy, In
Encyclopedia of Physical Science and Technology, 3rd edition. R. A. Meyers, ed. Academic Press, NY, 2002, 17, 921-938.

[39] E. B. Fox, A. F. Lee, K. Wilson, C. S. Song, Top. Catal., 2008, 49, 89-96.

[40] S. Cao, J. R. Monnier, C. T. Williams, W. J. Diao, J. R. Regalbuto, J. Catal., 2015, 326, 69-81.

[41] S. Alayoglu, G. A. Somorjai, Top. Catal., 2015, 59, 420-438.

[42] E. Taglauer, W. Heiland, Appl. Phys., 1976, 9, 261-275.

[43] M. Casagrande, S. Lacombe, L. Guillemot, V. A. Esaulov, Surf. Sci. Rep., 2000, 445, L36-L40.

[44] H. R. J. ter Veen, T. Kim, I. E. Wachs, H. H. Brongersma, Catal. Today, 2009, 140, 197-201.

[45] Z. Xu, H. M. Zhang, S. S. Liu, B. S. Zhang, H. X. Zhong, D. S. Su, Int. J. Hydrogen Energy, 2012, 37, 17978-17983.

[46] N. Barrabés, A. Frare, K. Föttinger, A. Urakawa, J. Llorca, G. Rupprechter, D. Tichit, Appl. Clay Sci., 2012, 69, 1-10.

[47] D. R. Butcher, M. E. Grass, Z. H. Zeng, F. Aksoy, H. Bluhm, W. X. Li, B. S. Mun, G. A. Somorjai, Z. Liu, J. Am. Chem. Soc., 2011, 133, 20319-20325.

[48] R. T. Mu, Q. Fu, H. Y. Liu, D. L. Tan, R. S. Zhai, X. H. Bao, Appl. Surf. Sci., 2009, 255, 7296-7301.

\title{
准原位XPS和HS-LEIS研究载体对PtCu合金纳米催化剂表面组成的影响
}

\author{
黄俊杰, 宋艳英, 马冬冬, 郑燕萍, 陈明树 ${ }^{*}$, 万惠霖 \\ 厦门大学化学化工学院, 固体表面物理化学国家重点实验室, 醇醚酯化工清洁生产国家工程实验室, 福建厦门361005
}

摘要: Pt是一类高效、稳定的催化剂, 但Pt资源短缺且价格昂贵, 限制了其广泛商业化应用. 合金化可以使Pt的用量大为减 少, 且往往能显著提高其催化性能, 因而广泛应用于多相催化和电催化. 其中PtCu合金是一类很有前景的催化剂, Cu资源 丰富、价格低廉, 不仅降低了成本, 而且由于合金效应提高了催化剂的活性和稳定性. 由于合金的粒径、形状、组成及结 构是影响其催化性能的重要因素, 目前研究大多关注这些特征的可控合成.

然而, 大多工业金属催化剂都是负载于氧化物上以提高催化性能, 合金纳米粒子的形貌以及表面组成因与载体作用而 发生改变, 也就是所谓的载体效应. 这体现在金属/氧化物界面处, 能够促进金属粒子分散、改变其形貌甚至化学态、进而 改变其催化性能, 其中最具代表性的金属-载体强相互作用. 因此, 研究不同氧化物载体上合金催化剂的分散度、表面组成、 化学态, 特别是不同气氛的影响, 对明确影响催化剂性能的关键控制因素非常重要. 但是由于多相催化剂的复杂性, 且表 面灵敏的测试手段很少, 目前相关报道还不多. 近年发展起来的高灵敏度低能离子散射谱(HS-LEIS)是表面层灵敏的测试 技术, 可以测定最表面层的组成和含量.

本文采用溶剂热共还原法成功制备了均一单相、粒径分布较窄的 $\mathrm{PtCu}_{x}$ 合金纳米颗粒, 并运用浸渍法将其负载在 $\mathrm{TiO}_{2}$ 载体上, 以保证载体上纳米粒子组成的均一性. 应用准原位X-射线光电子能谱(XPS)和高HS-LEIS对负载的PtCu合金纳米 催化剂在不同条件处理后的表面组成和化学状态进行表征, 发现催化剂的表面组成、分布、形貌和化学状态显著受到载体 和处理条件的影响, 同时得到负载和未负载的催化剂表面组成与体相组成关系的相图. 结果表明, $\mathrm{PtCu}_{x} / \mathrm{TiO}_{2}$ 催化剂在连 续氧化过程中, $\mathrm{Cu}$ 被氧化并较好在载体表面铺展, $\mathrm{Pt}-\mathrm{Cu}$ 合金状态被破坏, $\mathrm{Pt}$ 可能主要形成单一金属的纳米粒子, 并在界面 处形成 $\mathrm{Pt}^{\delta+}$. 在连续还原过程中, 部分被还原的 $\mathrm{Cu}$, 与 $\mathrm{Pt}$ 形成富 $\mathrm{Pt}$ 合金粒子. 催化剂表面层主要是 $\mathrm{Cu}, \mathrm{Pt}$ 很少, 与体相组成有 很大差别, 说明载体对 $\mathrm{Cu}$ 的分散起到重要作用.

关键词: 铂铜合金; 双金属催化剂; 表面组成; 相图; 原位X-射线光电子能谱-低能离子散射谱

收稿日期: 2017-04-11. 接受日期: 2017-05-12. 出版日期: 2017-07-05.

*通讯联系人. 电话/传真: (0592)2183723; 电子信箱：chenms@xmu.edu.cn

基金来源：国家重点基础研究发展计划(973计划, 2013CB933102); 国家自然科学基金(21273178, 21573180, 91545204); 厦门卓越 生物质柴油有限公司.

本文的英文电子版由Elsevier出版社在ScienceDirect上出版(http://www.sciencedirect.com/science/journal/18722067). 